$5-2020$

\title{
Assessment of Shopping Mall Customers' Experience through Criteria of Attractiveness in Tier-II and Tier-III Cities of India: An Exploratory Study
}

\author{
Ashish Gupta \\ Indian Institute of Foreign Trade, New Delhi, India, Under Ministry of Commerce and Industry, Govt. of \\ India \\ Vaibhav Mishra \\ ICFAI Business School, IFHE Campus Hyderabad (Deemed-to-be-University) Hyderabad \\ Anushree Tandon \\ Birla Institute of Management and Technology, Greator Noida, Uttar Pradesh
}

Follow this and additional works at: https://digitalcommons.newhaven.edu/americanbusinessreview

\section{Recommended Citation}

Gupta, Ashish; Mishra, Vaibhav; and Tandon, Anushree (2020) "Assessment of Shopping Mall Customers' Experience through Criteria of Attractiveness in Tier-II and Tier-III Cities of India: An Exploratory Study," American Business Review. Vol. 23 : No. 1 , Article 6.

DOI: https://doi.org/10.37625/abr.23.1.70-93

Available at: https://digitalcommons.newhaven.edu/americanbusinessreview/vol23/iss1/6 
Assessment of Shopping Mall Customers' Experience through Criteria of Attractiveness in Tier-II and Tier-III Cities of India: An Exploratory Study

\author{
Ashish Guptaa , Vaibhav Mishrab and Anushree Tandon ${ }^{\text {cd }}$
}

https://doi.org/10.37625/abr.23.1.70-93
American Business Review May 2020, Vol.23(1) $70-93$ (c) The Authors 2020, CC BY-NC ISSN: 2689-8810 (Online) ISSN: 0743-2348 (Print)

\begin{abstract}
The present research attempts to develop a theoretical framework for the assessment of shopping mall customer experience dimensions. It further classifies the variables associated with retail experiences that may attract customers in Tier-II and Tier- III cities towards the malls. Exhaustive literature review and expert opinion approaches have been used to explore the evaluation criteria for the assessment of the mall experience. ISM is used to develop a structural model that represents relationships among variables at different levels along with driving and dependence relationships in the structural model. The result highlights that factors like customer value orientation, tenant mix, employees, facilities management are the most significant benchmarking criteria for customers' assessment of their mall experience in the present study. To achieve profitable operations in these cities, retailer's need to acquaint themselves with the expectations of customers in order to attract their attention. This indicates that it is imperative for mall managers to identify how consumers benchmark different parameters while evaluating a mall experience. Understanding the importance of such parameters will allow malls to be built according to some standard specifications that can meet a consumer's threshold for appeal and attractiveness. The study adds to the existing literature of assessing shopping experience in Tier-II and Tier-III cities' malls through a structural model. The most and the least dominant factors found in this study will help mall managers to develop strategies to enhance the customer shopping experience in malls.
\end{abstract}

\title{
KEYWORDS
}

Attractiveness, Shopping Mall, Experience, Retail, Structural Model, India

Article classification: Research paper

\section{INTRODUCTION}

Customer experience has gained significant attention due to its potential for creating engaging as well as effectively managed retail spaces and environments (Dalmoro, Isabella, Almeida and dos Santos Fleck, 2019; Sadachar and Fiore, 2018). This concept has become ubiquitous in context of malls wherein customers can potentially derive benefits from the variety of outlets that are present within a mall's premises. Prior research has indicated that customers may derive such benefits from physical triggers

\footnotetext{
a Assistant Professor, Department of Marketing, Indian Institute of Foreign Trade (IIFT), New Delhi, India Under Ministry of Commerce and Industry, Govt. of India; Email: ashishgupta.vbn@gmail.com

${ }^{b}$ Assistant Professor, Department of Operations and IT, ICFAI Business School Hyderabad, IFHE University, Telangana, India; Email: cs.vaibhavmishra@gmail.com

c Retail Management Program, Birla Institute of Management Technology, India

d Turku School of Economics, University of Turku, Finland; Email: anushree.tandon7@gmail.com
}

Corresponding Author:

Anushree Tandon, anushree.tandon7@gmail.com 
as well as sensory triggers (Dalmoro et al., 2019). Yet, academic research is now focusing on developing a comprehensive understanding of experience dimensions that attract consumers to malls, especially in emerging economies such as India (Sadachar and Fiore, 2018). The present work tries to find the variables related to retail experiences that may attract customers in Tier II and Tier III cities towards malls in Indian context. It also tries to sequence the priorities of such factors using Interpretive Structural Modelling (ISM) and Matrice d'impacts Croises - multiplication applique ' a un classement (cross impact matrix-multiplication applied to classification) (MICMAC) analysis that may affect the customer satisfaction.

India's retail landscape has transformed in the past two decades and malls have become an integral part of this sector (Sadachar \& Fiore, 2018). This growth has been concentrated in urban and metropolitan regions of India but as indicated by Khare, Sarkar and Patel (2019), malls have not shown much promise in recent times. In fact, majority of malls in these regions are showing decreased profitability and significant signs of financial instability (Srivastava, Palande and Hussian, 2015; Khare et al., 2019). This detriment has been attributed to a variety of reasons such as high rentals, tenancy issues and lack of prime space (Srivastava et al., 2015). Subsequently, Indian mall developers and retailers are now turning their attention towards smaller cities and areas, also referred to as Tier II (population 1-4 million) and Tier III (population - less than 1 million) cities. The customers of these cities have been significantly influenced by changing economic ecosystem and fueled by the desire to improve their standards of living; they have been introduced to what may be called the 'Metro city lifestyle' (JLL - CII, 2017). These customers are driven towards malls due to conducive economic growth, extensive brand proliferation, access to information, media exposure, technological advancements, and increased opportunities for shopper - retailer interactions (PwC 2012; AT Kearney, 2012; JLL - Cll, 2017).

In 2008, the advertising agency 'RK Swamy BBDO' in its Guide to Market Planning surmised that at least one city in every 51 Indian districts had population exceeding five lacks people (Tier III city) and that all such cities together had twice the market potential of India's top four metropolis, namely, Mumbai, New Delhi, Chennai and Kolkata (Business Monitor International, 2012). Dungarwal (2016) estimated that whereas a mall based in the city can offer a return of $10-1$ percent, a mall based in a small town can give a significantly higher rate of return at approximately $18-24$ percent. Encouraged by the potential of such cities, retailers are driven towards establishing their presence in such Tier II \& Tier III cities leading to malls' growth, in these cities (Khare \& Rakesh, 2010; PwC \& FICCI, 2012; AT Kearney, 2012; Singh \& Srinivasan, 2012; JLL-CII, 2017). It is posited that of the 65 million square feet of retail space expected to be developed in India by 2020, approximately 18.2 million square feet would be developed in Tier II and III cities (Babar and Khan, 2019).

However, to achieve profitable operations in these cities, retailers need to acquaint themselves with the expectations of customers in order to attract their attention. Such expectations can help retailers and mall managers in developing benchmarks for mall experiences that can promote the adoption and execution of some standardized measures of customers' mall experiences. The present work tries to delineate the variables related to retail experiences that may attract customers in Tier II and Tier III cities towards the malls. Furthermore, this study attempts to establish relationships between these variables with the use of Interpretive Structural Modelling (ISM) and Matrice d' Impacts Croises Multiplication Appliqué an Classement (MICMAC) analysis.

\section{LITERATURE REVIEW}

Malls, which provide attractive offers to customers, fulfill their needs and expectations may become destination attractions for them (Ooi and Sim, 2007). This suggests that it is imperative for the mall 
managers to gain insight into consumers' process for benchmarking different evaluative parameters of their experiences in a mall. Such insights into the importance of evaluative parameters will allow malls to be built according to some standard specifications that can meet a consumer's threshold for appeal and attractiveness.

Past research indicates, customer experience creation holds a wide scope for research in context of emerging markets such as India. Previous researches have aimed at theoretical concepts of developing commercial experiences and in Indian context most researches are generic in nature. Academic knowledge especially in context of the smaller towns and cities in such markets is limited (Ghosh et al., 2010; Khare, 2011) with extant research being focused on consumer behaviour in metropolitan cities (Singh \& Prashar, 2014; Kesari \& Atulkar, 2016; Paul, 2017). The present study tries to address this gap by studying mall attaractivess in small towns such as Tier-II and Tier- III cities of India. The factors indentified through this study may help retailers to devise suitable retail mix strategies to enhance consumers' mall experiences and bridge the extant knowledge gap. This could enhance mall attractiveness which is specific to Indian customers residing in Tier II and III cities. Prior studies have also utilized similar methodological approaches to study the Indian economy. For example, using Interpretive Structural Modelling (ISM) approach and Fuzzy Matrice d' Impacts Croises Multiplication Appliqué an Classement (FMICMAC) analysis, Singh and Samuel (2018) identified the relationship between competitiveness of apparel retail sector with simultaneous determination of factors having an impact on competitiveness and their development. With the increased competitiveness, retailers operating in India are trying to differentiate themselves by attempting to create retail environments comprising of tangible and intangible stimuli which can trigger the formation of memorable experiences. Jain and Ajmera (2018) explored drivers influencing the medical tourism sector to make medical tourism reasonable in India. Factors were explored by conducting literature review and ISM method was used for analysis. Khan and Rahman (2017) also identified Hotel Brand Expereince (HBE) related factors and determined the relationship among them by developing a reliable and vigorous hierarchy-based model through ISM approach. Verma and Singh (2018) applied ISM to establish interrelationship between important variables stimulating India e-impulse buying behavior though 30 in-depth interviews.

\section{Retail Experiences}

From 2000 onwards, coupled with the sheer market size, growing consumerism, rapid urbanization and Indian consumers' enthrallment with organized retail; the infrastructural developments have resulted in expeditious growth in this sector and its emergence as a prominent retail destination (A.T. Kearney, 2012; KPMG, 2014). Ranked in the top 30 by the A.T. Kearney's Global Retail Development Index since 2005, and $15^{\text {th }}$ in 2015, the retail sector of India has witnessed 10.6\% growth during 2010 to, 2012 (Jones Lang LaSalle, 2012) and will continue to witness a CAGR of 12 to 13 percent in the next few years (KPMG, 2014, CARE Ratings, 2019). Bolstered by the economic growth of the nation, plans for domestic retail chains expansion, inundation of Multi-National Corporations (MNCs) as well as infrastructural development has fueled the organized retail sector and its value is likely to rise from a currently estimated USD 22 billion to and register an estimated value of USD 1,150 billion by 2021 end (CARE Ratings, 2019). In the competitive Indian retail landscape, scholars' theories that creation of unique, entertaining shopper experiences may work as a vital function to develop and maintain a mall's competitive edge (Wakefield and Baker, 1998; Backstrom, 2006; Tsai, 2010). 


\section{Mall Experiences}

Malls hold immense potential for offering holistic experiences to shoppers and have become entertainment, recreation and socialization hotspots (Banerjee, 2012; Singh and Sahay, 2012). However, previous studies have mainly aimed at understanding theoretical concepts of developing commercial experiences. Also, in Indian context most researches have been generic (Tandon, Tripathi and Gupta, 2014) and focused on conceptualization of experiential elements, such as, stimulating customer returns in malls (Srinivasan and Srivastava, 2010), profiling of mall shoppers (Kuruvilla and Joshi, 2010) and measuring attitude of customer towards malls (Swaminathan and Vani, 2008; Banerjee, 2012).

\section{Research Variables}

\section{Merchandise/ Assortment}

Customer expectations of depth and breadth of merchandise affects consumer attitude (Mazursky \& Jacoby, 1986) and acts as drivers for store/ outlet selection (Baltas \& Papastathopoulou, 2003; Majumdar, 2005; Ghosh, Tripathi \& Kumar, 2010). By frequently updating and tuning merchandise mix (Willems et. al., 2012) to meet the changing customer demands (Grewal, Levy \& Kumar, 2009), assortment can also act as tool for customer engagement (Puccinelli et. al., 2009). Unique product assortments can add experiential value for customers (Arnould et. al., 2002; Grewal, Levy \& Kumar, 2009) can help retailers to create a differentiated image (Terblanche \& Boshoff, 2004; Arnould et. al., 2002; Sorescu et. al., 2011; Yu \& Bastin, 2010). An integral component of retail strategic decisions; the quality and variety of merchandise not only helps fulfil consumers' basic expectations from retailers', but also significantly facilitates the creation of a pleasant shopping experience (Torres, Summers \& Belleau, 2001; Terblanche \& Boshoff, 2004; Tsai, 2010; Sorescu et. al., 2011; Davis and Hodges, 2012).

\section{Employees}

Positive interactions between frontline employees and customers are an antecedent to consumer satisfaction which generates positive behavioral intentions like word of mouth suggestions. In fact, Kang \& Hyun (2012) suggest that employees induce three major dedicational behaviors of relationship enhancement, cooperation and advocacy by enhancing customer service (Blocker et. al., 2011), reducing complaints (Velasquez et. al., 2010); enhancing perceived pleasantness of experience (Oliver, 1994) and derived value (Ramaswamy, 2009; Ferguson, Bergeron \& Paulin, 2010; Angelis et. al., 2010). Studies (Joseph-Mathews et. al., 2009; Blocker et. al., 2011; Velasquez et. al., 2010) suggest that employees' and their orientation are critical to link in establishing between the retailer and customer (Yuan \& Wu, 2008; Webster \& Sundaram, 2009). Employees who lack qualities such as approachability, communicability, patience and congeniality (Hean \& Tin, 2004) are unable to establish rapport with customers (Adufutse, 2010) which is crucial for delivering an individualized experience (Gunter, 2007).

\section{Convenience/ Accessibility}

For customers in Tier III cities, a retailers' attractiveness is considerably influenced by issues such as the distance of mall from residence or workplace (Abghari \& Hanzaee, 2011), availability of transport to/from location (Ghosh, Tripathi \& Kumar, 2010), tenant placement and convenience of movement inside mall premises (Abghari \& Hanzaee, 2011; Bonnin \&Goudey, 2012). The facilitation of convenience 
or accessibility is an antecedent to proactively meeting customer demands (Donelly,2009); especially those of economic, price - conscious customers due to reduction in terms of perceived psychic costs, that is, money, effort and cost accrued (Singh, 2006). Convenience enhances the perceptions of derived functional value from the retailer (Yuan \& Wu, 2008) and is significant in meeting customer expectations for development of loyalty and good relationship with customers (Arnould et. al., 2002; Mascarenhas, Kesavan \& Bernacchi, 2006; Kim, 2007; Srivastava \& Kaul, 2014).

\section{Pricing}

Price is a significant moderator that can help retailers to involve customers (Biswas, Grewal \& Roggeveen, 2010) and influence their purchase decisions (Grewal, Levy \& Kumar, 2009). Promotions and discounts can drive sales and impact retailers' profit margins (Backstrom, 2006). Grewal, Levy and Kumar (2009) discuss retailer pricing strategies and propose that price can 'capture' customers' perceived value, affect sales of complimentary products and have significant implication for category management decisions as well as assortment planning. Though Fornell et. al. (1985) argue that price is a less significant factor while considering experience, the price conscious nature of Indian Tier III customers lend this factor considerable significance in evaluating retailer attractiveness, as they would be more attracted towards retail formats which offer considerable variety in terms of price ranges (Majumdar, 2005; Sanguanpiyapan \& Jasper, 2010). Yuan and Wu (2008) argue that price affects customer perception of functional value (Rajaguru \& Jekanyikamatanda, 2011) and influences on customers' derivation of experiential value. Donelly (2009) submits that prices can indirectly affect customer experience and loyalty, by affecting their satisfaction.

\section{Tenant Mix}

An appropriate tenant mix can significantly enhance retail/ mall attractiveness (Majumdar, 2005). The changes in customer psychographics has resulted in their lookout for a one stop convenient shopping experience and they are more likely to gravitate towards malls which provides a variety of tenants to their shoppers to fulfill their myriad of needs. An optimal tenant mix in a mall would include a variety of complimentary retail and non - retail tenants such as eateries, entertainment and bar facilities (Abghari \& Hanzee, 2011). Such favorable tenant mix and management by mall managers can help them create holistic experience for customers leading for expanding the retail sales prospects (Teller \& Reutterer, 2008). The tenant mix should be tailored as per the location of mall, demographic profile of the catchment area, Built - Up Area and Gross Leasable Area and the (The Institute of Real Estate Management, 1990). The catchment area analysis can help identify appropriate variety tenants with differing target groups which would better attract customers (Srinivasan \& Srivastava, 2010; Rajagopal,2011). Additionally, availability of tenant variety gives customers the opportunity to experience 'hybrid consumption' which is both functional and hedonic. This would create an engaging atmosphere and induces greater duration of stay.

\section{Crowd Management}

A complex phenomenon, crowding may be defined as customers' response to human density in a retail setting (Baker \& Wakefield, 2012) or the number of people in an outlet at a certain point of time (Garg, Rehman \& Kumar, 2010). Though the customers' perception of crowding is affected by their personal tolerance levels, spatial layout of the store (Garg, Rehman \& Kumar, 2010; Baker \& Wakefield, 2012), the management of crowds by the retailer; the customers' orientation and purpose of visit also play 
an important part in establishing their relation with crowd (Eroglu \& Machleit, 1990; Machleit et. Al., 1994; Eroglu et. Al., 2005). Studies posit that crowd influences consumer's retail experience (Pons et. Al., 2006) However, this impact may be positive (Eroglu et. Al., 2005) as well as positive (Grewal et. Al., 2003).

\section{Entertainment/ Enjoyment Potential}

Most modern customers experience malls as organized arenas where they can not only fulfill their functional shopping goals; but also enjoy leisure, social interaction and recreational activities (Wakefield \& Baker, 1998; Michon et. al., 2008; Khare \& Rakesh, 2010; Borges, Chebat \& Babin, 2010). Defined as an environment that pleases, amuses or diverts the mind (Pine \& Gilmore, 1999); entertainment provides customers with sensory stimulation capable of eliciting emotional responses such as loyalty, recommendation and appreciation (Poulsson \& Kale, 2004). Customers' perception of a mall's entertainment potential is capable of making the mall seem unique and attractive (Tsai, 2010). The opportunities for entertainment offer customers a subtle return on investment towards the time, effort and money spent on the mall and is a credible source of value (Davis \& Hodges, 2012).

\section{Parking}

Due to the economic growth of the nation, many Indians have attained the ownership of two/four wheeled vehicles. For such customers, parking facility is an important micro- accessibility factor which contributes to enhancing a mall's attractiveness (Majumdar, 2005). A utilitarian benefit, parking positively influences customers' experiences and provides functional value to them (Pine \& Gilmore, 1999; Carbone \& Haeckel, 2005; Kim, 2007; Han, Back \& Barrett, 2010). The availability of adequate, as well as safe parking sites, act as a 'pull' factor and are a primary factor of mall attractiveness (Parekh, Manjrekar \& Subramanian, 2011). Its availability may affect customers' re-visit intentions, generate positive word - of - mouth (Carbone \& Haeckel, 2005) and act as an external atmospheric cue (Puccinelli et. al., 2009); all of which are indicative of an emotional response to satisfaction with the functional experience of visiting a mall.

\section{Facilities Management}

Facilities management includes a range of activities to manage built assets like furniture, equipment's i.e. hardware and safety, human resources, and support services i.e. software (Hui et. al., 2013) required for smooth conduction of business and achieving Organizational goals (Musa and Pitt, 2009). Hui et. al (2013) identified those dimensions of facilities management which had a significant and positive impact on shoppers including, management of communal facilities (such as escalators and elevators), supply of drinking water, cleanliness of washroom, various facilities provided in washrooms, maintenance of flooring and its cleanliness and management of decorations in common areas. Such facilities may also include washrooms, signage, lifts and escalators, public phones and cash machines etc. that impact shopper's experience and justifies owner/builders' investment (Shaw and Haynes, 2004; Musa and Pitt, 2009; Hui et. al., 2011; Hui et. al, 2013).

\section{Customers' Value Orientation}

Apart from product/ purchase related value, customers may derive value from emotions experienced during their interactions with the retail environment, which is independent of the economic value of 
the product (Pine \& Gilmore, 1999; Allen, 2009). Customers' expectation of the type of value they wish to derive, or their value orientation have been receiving increased attention by academicians which indicated that shopping or visiting a retail outlet may no longer be the means to an end (Davis \& Hodges, 2012). Instead, such value may be argued to be multi - dimensional incorporating elements of hedonism or pleasure seeking, utilitarianism and social leisure etc. (Batra \& Ahtola, 1991; Babin et. al., 1994; Voss et. al., 2003; Allen, 2009) This value orientation may be characterized as drivers or motivators of behavior which encourage customers' behavioral intention while visiting marketplaces as well as their subsequent actions (Tauber, 1972; Arnold \& Reynolds, 2003; Cinjarevic et. al., 2011).

\section{Customer Satisfaction}

Customer satisfaction is transaction specific evaluation of consumed product, service or experience and is an integral part of marketing theory as well as practice (Rondeau \& Wagar, 2006). Babin et. al. (1994) suggest that customers' satisfaction levels are affected by their value orientation, along with other factors such as crowding (Garg, Rehman \& Kumar 2010), accessibility to retail outlet (Abghari \& Hanzaee, 2011), facilities management (Hui et. al.,2013), price range (Rajagopal, 2011) etc. Several researchers have found a strong connection among the factors like behavioral intentions, customer satisfaction re-patronage, loyalty \& recommendation (Abghari \& Hanzaee, 2011; Ryu \& Han, 2011; Oliver, 1994).

Table 1: Variables effecting customer experience in mall setting for enhancing customer satisfaction

S. No Variables Supporting Studies

Baltas and Papastathopoulou, 2003; Terblanche and Boshoff, 2004;

1. Merchandise/ Assortment Majumdar, 2005; Arnould et. al., 2002; Yu and Bastin, 2010; Ghosh, Tripathi \& Kumar, 2010; Sorescu et. al., 2011; Yu \& Bastin, 2010; Rahman et al., 2020.

2. Employees Behaviour

3. Convenience/ Accessibility

4. Pricing

5. Tenant Mix

6. Crowd Management

7. Entertainment/

7. Enjoyment Potential

8. Parking

9. $\quad$ Facilities

10. Customers Value

10. Orientation
Anselmsson, 2007; Joseph-Mathews et. al., 2009; Blocker et. al., 2010; Velasquez et. al., 2010.

Arnould et. al., 2002; Singh, 2006; Kim, 2007; Yuan and Wu, 2008; Donnelly, 2009; Ghosh, Tripathi and Kumar, 2010.

Backstrom, 2006; Pan and Shankar, 2008; Donnelly, 2009; Biswas, Grewal and Roggeveen, 2010; Rajaguru and Jekanyikamtanda, 2011; Chi and Kilduff, 2011.

Majumdar, 2005; Teller \& Reutterer, 2008; Srinivasan \& Srivastava, 2010; Rajagopal, 2011; Abghari and Hanzee, 2011; Ammani, 2013.

Eroglu \& Machleit, 1990; Machleit et. al., 1994; Eroglu et. al., 2005; Garg, Rehman and Kumar, 2010; Baker and Wakefield, 2012.

Wakefield and Baker, 1998; Pine and Gilmore, 1999; Michon et. al., 2008; Khare and Rakesh, 2010; Davis and Hodges, 2012.

Pine \& Gilmore, 1999; Carbone \& Haeckel, 2005; Kim, 2007; Han, Back and Barrett, 2010; Parekh, Manjrekar and Subramaniam, 2011.

Shaw and Haynes, 2004; Musa and Pitt, 2009; Hui et. al., 2011; Hui et. al, 2013.

Tauber, 1972; Batra and Ahtola, 1991; Arnold and Reynolds, 2003; Babin et. al., 1994; Voss et. al., 2003; Allen, 2009; Cinjarevic et. al., 2011. 
11. Customer
Satisfaction
Oliver, 1994; Rondeau et. al., 2006; Garg, Rehman and Kumar, 2010; Abghari and Hanzaee, 2011; Ryu and Han, 2011.

\section{ISM METHODOLOGY}

Interpretive Structural Modelling (ISM), an interactive learning process, identifies the relationships among specific constructs which define an issue or a problem (Warfield, 1976; Sage, 1977). This methodology has been used in many studies for imposing order and disintegrating complex relationships among items (Sage, 1977; Sahney et al., 2010; Faisal et al., 2006). ISM methodology helped Sarmah and Rahman (2018) to determine the relationship between service innovation variables of hotels and customer satisfaction. They also suggested that hoteliers may improve their services by analyzing psychological factors playing crucial role in hospitality sector. Similarly, Singh et al. (2017) developed a model for green supply chain management which when implemented can change the current practices of fertilizer industry. It has found wide applicability in processing and structuring details related to any issue or activity such as career planning, process re-engineering, operations problem, strategic planning, product design, process design, complex technical problems, human resources, financial decision making, electronic commerce, healthcare, lean manufacturing, cloud computing adoption and competitive analysis (Faisal et al., 2006; Sahney et al., 2010; Attri et al., 2017; Sushil, 2018; Khaba and Bhar, 2018; Raut et al., 2018; Chaple et al., 2018; Ajmera and Jain, 2019). In retailing context, Venkatesh et al., (2015) used ISM in identifying supply chain risk variables in Indian apparel retail chain. Similarly, Khan and Rahman (2015) used this approach in understanding retail brand experience.

Table 2: List of variables that may enhancing the customer satisfaction

\begin{tabular}{clcl} 
S. No. & Customer Satisfaction Variables & S. No. & Customer Satisfaction Variables \\
\hline 1. & Merchandise/ Assortment & 2. & Entertainment/ Enjoyment Potential \\
3. & Employees Behaviour & 4. & Parking \\
5. & Convenience/ Accessibility & 6. & Facilities Management \\
7. & Pricing & 8. & Customers Value Orientation \\
9. & Tenant Mix & 10. & Customer Satisfaction \\
11. & Crowd Management & & \\
\hline
\end{tabular}

ISM focuses on groups or paired comparison, helps group of people to structure their corpus of knowledge as these group decide whether and how items are related. However, unlike these techniques, ISM adopts mathematical algorithms which minimizes the several queries required to explore relationships among number of ideas. Thus, ISM is both, quantitative and qualitative in nature (Georgakopoulos, 2009). The model developed using this methodology depicts the structure of a problem or complex matter in a plotted design suggesting both words and graphics (Rajesh et al. 2007). Kumar and Purbey (2018) developed a framework of factors effecting the formation of negative electronic word of mouth at review. Review of literature and group judgment method were used to find the items that influenced negative word of mouth and ISM was used to form a structural model that depicted relationships among items. 
Table 3: Participants and process details

\begin{tabular}{|c|c|c|}
\hline S.No. & $\begin{array}{l}\text { Participants/ } \\
\text { Process }\end{array}$ & Explanations \\
\hline 1. & Participants & $\begin{array}{l}\text { (1) Group A: Including e.g. Carrier (Store Manager, } 8+\text { years corporate work } \\
\text { experience); Professor (PhD, 10+ year academic work experience) } \\
\text { (2) Group B: Including e.g. Exporter (Senior Manager, } 11 \text { years corporate } \\
\text { work experience); Professor (former - Area Head, } 14 \text { years total experience) } \\
\text { (3) Delphi Panel Including e.g. Group A, Group B, Marketing Manager with } \\
\text { more than } 5 \text { years total experience) }\end{array}$ \\
\hline 2. & Round 1 & $\begin{array}{l}\text { Both the groups (Group A and Group B) decides the intensity of } \\
\text { relationships between two variables that affect the customer satisfaction. }\end{array}$ \\
\hline 3. & Round 2 & $\begin{array}{l}\text { written statement regarding the reasons for their decisions in respect of } \\
\text { the discrepancies. } \\
\text { (2) After exchanging the written statements, both the groups make their } \\
\text { final decision on the pairwise relationships. }\end{array}$ \\
\hline 4. & Round 3 & $\begin{array}{l}\text { (1) If there are still any discrepancies, the members of the Delphi panel } \\
\text { review the relationships until they reach a consensus. } \\
\text { (2) The decisions on the contextual relationships among the elements that } \\
\text { affect the customer satisfaction are finalized. }\end{array}$ \\
\hline
\end{tabular}

To take a cohesive decision on the relationship among factors that may affect customer satisfaction in mall management, there has a need develop a model, here we have adopted ISM-based model and a Delphi study was taken up as the third stage to refine ideas and to reach at a common consensus among all participants who has good experience in corporates and academics and they are associated with mall management, customer service and satisfaction (refer Table 3).

The 55 pair-wise relationship-based suggestions has been generated from 11 customer satisfaction elements (Refer Table 2). The participants in group A and group B discussed the relationships between element $\mathrm{i}$ (1-11) and element $\mathrm{j}$ (1-11) on a pairwise basis, and allocated arrows to denote the direction. After round 1, 30 discrepancies were found and the summary of that has been given to both group for further changes in their personal suggestions, then after round 2 total discrepancies were reduced to 10 , which were again raised among Delphi panel and finally we got common consensus (Refer Figure 1). 


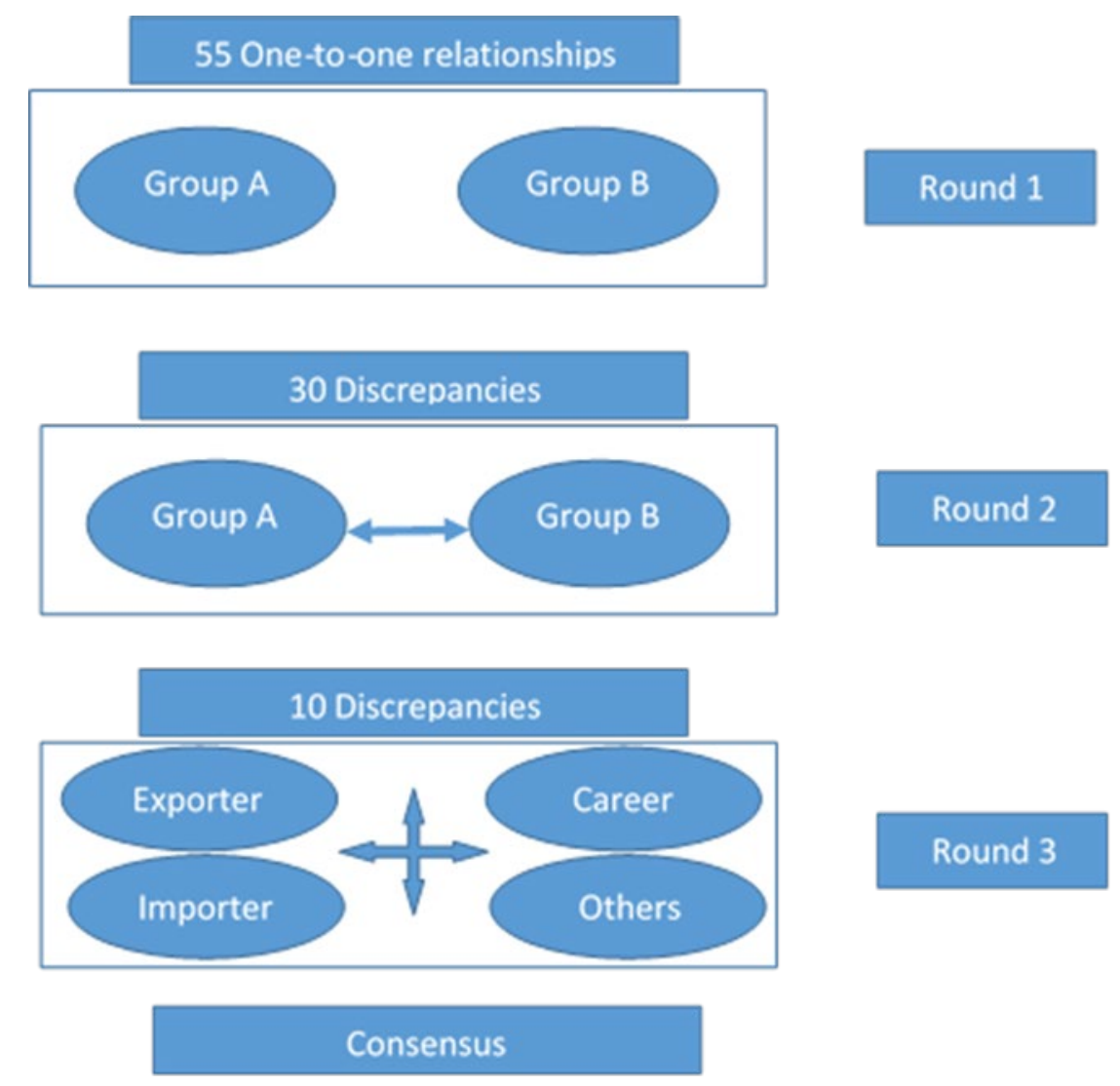

Figure 1: The Delphi Process

\section{Procedures and Applications}

In the suggested ISM Procedure, an Initial meeting with group of experts, from industries (three retail practitioners with more than 5 years of experience) and the academics (five marketing professors) were conducted to identify, both nature and contextual relationships among the factors. List of articles included for the study was circulated among the experts and the academicians to reach consensus on the articles included. Seven days later, for the application of ISM, a brainstorming session was organized with the experts and the academician to explore the factors that impact customer experience in mall (see Table 4). Initially, fourteen factors were found, which was further reduced to eleven as some of them were not significant to evaluate customer experience in the mall.

\section{Structural Self-Interaction Matrix (SSIM)}

In order to develop a contextual "leads to" relationship among the listed factors, opinion of experts were taken. Personal interview of four experts-two academicians, one researcher, one Industry expert, was conducted. To establish the relationship among various factors following conditions were considered:

- A, If ' $i$ ' is predictor of ' $j$ '.

- $\quad B$, If ' $j$ ' is predictor of ' $i$ '.

- C, If 'i' and 'j' predict each other.

- $\quad$, If no predict each other. 
Table 4: Structural Self-Interaction Matrix (SSIM)

\begin{tabular}{|c|c|c|c|c|c|c|c|c|c|c|c|}
\hline S. No. & Elements & 11 & 10 & 9 & 8 & 7 & 6 & 5 & 4 & 3 & 2 \\
\hline 1. & Merchandise/ Assortment & $A$ & $C$ & $D$ & $D$ & $D$ & $D$ & $C$ & $C$ & $D$ & $D$ \\
\hline 2. & Employees & $A$ & $A$ & $A$ & D & D & $A$ & $C$ & $D$ & $D$ & - \\
\hline 3. & Convenience/ Accessibility & $A$ & $B$ & $B$ & $C$ & $A$ & $B$ & D & $D$ & - & - \\
\hline 4. & Product Pricing & $A$ & $C$ & D & $D$ & $D$ & $A$ & $D$ & - & - & - \\
\hline 5. & Tenant Mix & $A$ & $A$ & $D$ & $D$ & $A$ & $A$ & - & - & - & - \\
\hline 6. & Crowding & $A$ & $B$ & $B$ & $C$ & $B$ & - & - & - & - & - \\
\hline 7. & Entertainment/Enjoyment Potential & $A$ & $C$ & $B$ & $D$ & - & - & - & - & - & - \\
\hline 8. & Parking & $A$ & $A$ & $D$ & - & - & - & - & - & - & - \\
\hline 9. & Facilities Management & $A$ & $A$ & - & - & - & - & - & - & - & - \\
\hline 10. & Customers Value Orientation & $A$ & - & - & - & - & - & - & - & - & - \\
\hline 11. & Customer Satisfaction & - & - & - & - & - & - & - & - & - & - \\
\hline
\end{tabular}

\section{Reachability Matrix}

The SSIM is converted to a binary matrix by substituting A, B, C and D by 1 and 0 as per given case. This matrix is known as initial reachability matrix. Following rules are applied for the substitution of $1 \mathrm{~s}$ and os:

Table 5: Reachability MATRIX

\begin{tabular}{ccc}
\hline$(\mathbf{i}, \mathbf{j})$ entry in SSIM & Reach ability matrix entry & $(\mathbf{j}, \mathbf{i})$ entry \\
\hline A & 1 & 0 \\
B & 0 & 1 \\
C & 1 & 1 \\
D & 0 & 0 \\
\hline
\end{tabular}

Table 6 shows the initial reachability matrix for the variables along with the driving power and dependence of each variable. These driving power and dependencies will be used later to categorize variables into the four categories, namely, autonomous, dependent, linkage and independent (driver) variables.

- $A$, If ' $i$ ' is predictor of ' $j$ ', then $(i, j)$ is 1 and $(j, i)$ is 0

- $B$, If ' $j$ ' is predictor of ' $i$ ' then $(j, i)$ is 1 and $(i, j)$ is 0

- $\quad C$, If ' $i$ ' and ' $j$ ' predict each other then $(i, j)$ is 1 and $(j, i)$ is 1

- $D$, If no predict each other then $(i, j)$ is 0 and $(j, i)$ is 0 
Table 6: Initial Reachability Matrix

\begin{tabular}{|c|c|c|c|c|c|c|c|c|c|c|c|c|c|}
\hline & Elements & 1 & 2 & 3 & 4 & 5 & 6 & 7 & 8 & 9 & 10 & 11 & $\begin{array}{l}\text { Power } \\
\text { Driving }\end{array}$ \\
\hline 1. & $\begin{array}{l}\text { Merchandise/ } \\
\text { Assortment }\end{array}$ & 1 & 0 & 0 & 1 & 1 & 0 & 0 & 0 & 0 & 1 & 1 & 5 \\
\hline 2. & Employees & 0 & 1 & 0 & 0 & 1 & 1 & 0 & 0 & 1 & 1 & 1 & 6 \\
\hline 3. & $\begin{array}{l}\text { Convenience/ } \\
\text { Accessibility }\end{array}$ & 0 & 0 & 1 & 0 & 0 & 0 & 1 & 1 & 0 & 0 & 1 & 4 \\
\hline 4. & Pricing & 1 & 0 & 0 & 1 & 0 & 1 & 0 & 0 & 0 & 1 & 1 & 5 \\
\hline 5. & Tenant Mix & 1 & 1 & 0 & 0 & 1 & 1 & 1 & 0 & 0 & 1 & 1 & 7 \\
\hline 6. & Crowd Management & 0 & 0 & 1 & 0 & 0 & 1 & 0 & 1 & 0 & 0 & 1 & 4 \\
\hline 7. & $\begin{array}{l}\text { Entertainment/ } \\
\text { Enjoyment Potential }\end{array}$ & 0 & 0 & 0 & 0 & 0 & 1 & 1 & 0 & 0 & 1 & 1 & 4 \\
\hline 8. & Parking & 0 & 0 & 1 & 0 & 0 & 1 & 0 & 1 & 0 & 1 & 1 & 5 \\
\hline 9. & Facilities Management & 0 & 0 & 1 & 0 & 0 & 1 & 1 & 0 & 1 & 1 & 1 & 6 \\
\hline 10. & $\begin{array}{l}\text { Customers value } \\
\text { Orientation }\end{array}$ & 1 & 0 & 1 & 1 & 0 & 1 & 1 & 0 & 0 & 1 & 1 & 7 \\
\hline \multirow[t]{2}{*}{11.} & Customer Satisfaction & 0 & 0 & 0 & 0 & 0 & 0 & 0 & 0 & 0 & 0 & 1 & 1 \\
\hline & Dependence & 4 & 2 & 5 & 3 & 3 & 8 & 5 & 3 & 2 & 8 & 11 & \\
\hline
\end{tabular}

\section{Level Partitions}

Final reachability matrix helps to find reachability and antecedent set for each barrier (Warfield, 1976). The reachability set includes element itself and other elements, which it may help achieve. The antecedent set includes element itself and the other elements, which may help achieving it. Then the intersection of these sets is derived for all elements. The element having same intersection sets and reachability set is considered the top- level element in the ISM hierarchy.

Table 7: Reachability Matrix: First Iteration

\begin{tabular}{|c|c|c|c|c|}
\hline Variable & $\begin{array}{c}\text { Reachability Set } \\
\text { (Row) }\end{array}$ & $\begin{array}{c}\text { Antecedent Set } \\
\text { (Column) }\end{array}$ & Intersection Set & Leve \\
\hline 1 & $1,4,5,10,11$ & $1,4,5,10$ & $1,4,5,10$ & \\
\hline 2 & $2,5,6,9,10,11$ & 2,5 & 2,5 & \\
\hline 3 & $3,7,8,11$ & $3,6,8,9,10$ & 3,8 & \\
\hline 4 & $1,4,6,10,11$ & $1,4,10$ & $1,4,10$ & \\
\hline 5 & $1,2,5,6,7,10,11$ & $1,2,5$ & $1,2,5$ & \\
\hline 6 & $3,6,8,11$ & $2,4,5,6,7,8,9,10$ & 6,8 & \\
\hline 7 & $6,7,10,11$ & $3,5,7,9,10$ & 7,10 & \\
\hline 8 & $3,6,8,10,11$ & $3,6,8$ & $3,6,8$ & \\
\hline 9 & $3,6,7,9,10,11$ & 2,9 & 9 & \\
\hline 10 & $1,3,4,6,7,10,11$ & $1,2,4,5,7,8,9,10$ & $1,4,7,10$ & \\
\hline 11 & 11 & $1,2,3,4,5,6,7,8,9,10,11$ & 11 & 1 \\
\hline
\end{tabular}


However, top-level element of the hierarchy will not aid in achieving any other element above their own. On identifying top level element (Refer Table 7), it is isolated from the rest. The process is rerun to find elements in the next level. This process is reiterated till each element's level is found (Refer Table 8). The levels found in the process aids to build the diagraph and the model. Table 8 shows the final reachability matrix which includes all reachability and antecedents sets with the level partitions.

Table 8: Final Reachability Matrix with Levels of variables influencing customers' experience of malls in Tier III Cities

\begin{tabular}{ccccc}
\hline Variable & $\begin{array}{c}\text { Reachability Set } \\
\text { (Row) }\end{array}$ & $\begin{array}{c}\text { Antecedent Set } \\
\text { (Column) }\end{array}$ & Intersection Set & Level \\
\hline $\mathbf{1}$ & $1,4,5,10,11$ & $1,4,5,10$ & $1,4,5,10$ & $\mathrm{VI}$ \\
$\mathbf{2}$ & $2,5,6,9,10,11$ & 2,5 & 2,5 & $\mathrm{IV}$ \\
$\mathbf{3}$ & $3,7,8,11$ & $3,6,8,9,10$ & 3,8 & $\mathrm{II}$ \\
$\mathbf{4}$ & $1,4,6,10,11$ & $1,4,10$ & $1,4,10$ & $\mathrm{VI}$ \\
$\mathbf{5}$ & $1,2,5,6,7,10,11$ & $1,2,5$ & $1,2,5$ & $\mathrm{VII}$ \\
$\mathbf{6}$ & $3,6,8,11$ & $2,4,5,6,7,8,9,10$ & 6,8 & $\mathrm{II}$ \\
$\mathbf{7}$ & $6,7,10,11$ & $3,5,7,9,10$ & 7,10 & $\mathrm{II}$ \\
$\mathbf{8}$ & $3,6,8,10,11$ & $3,6,8$ & $3,6,8$ & $\mathrm{III}$ \\
$\mathbf{9}$ & $3,6,7,9,10,11$ & 2,9 & 9 & $\mathrm{~V}$ \\
$\mathbf{1 0}$ & $1,3,4,6,7,10,11$ & $1,2,4,5,7,8,9,10$ & $1,4,7,10$ & $\mathrm{VIII}$ \\
$\mathbf{1 1}$ & 11 & $1,2,3,4,5,6,7,8,9,10,11$ & 11 & $I$ \\
\hline
\end{tabular}

\section{Formation of ISM-based Model}

The structural model is developed from the final reachability matrix (refer (Table 8) through lines of edges and vertices or nodes. The relationship, if it exist, between the variables $(\mathrm{i}, \mathrm{j})$ is depicted by an arrow pointing from $\mathrm{i}$ to $\mathrm{j}$. The graph is known as directed graph or digraph. After removing the transitivity, the final diagraph is developed (Figure 2), which is then converted into ISM (Figure 3). 


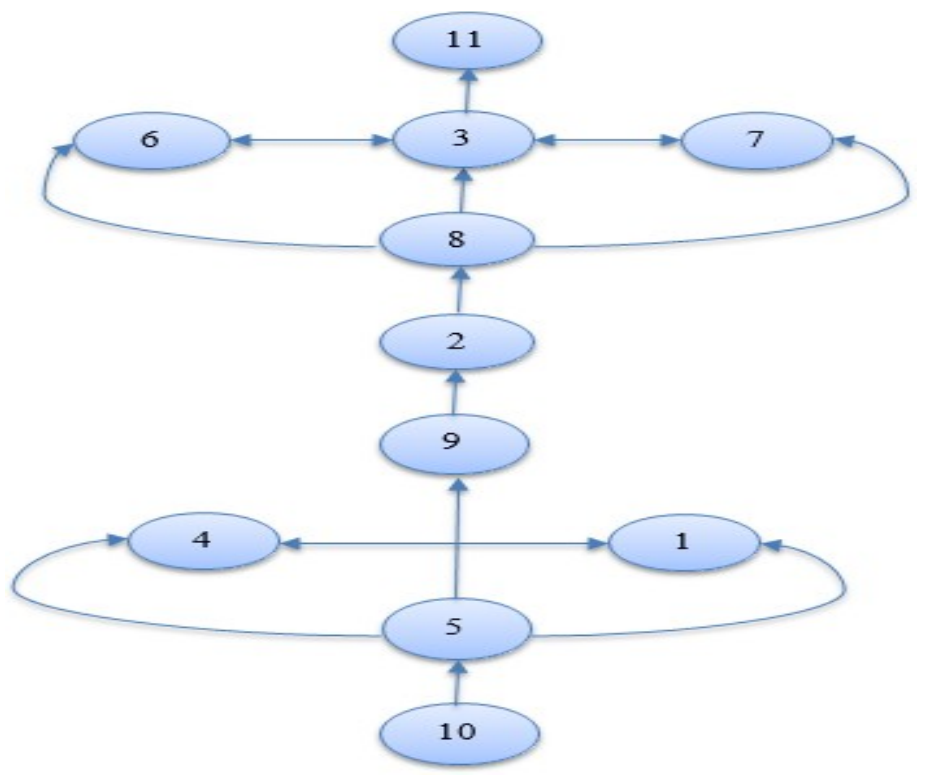

Figure 2: Final diagraph depicting the relationship among the customer experience and mall attractiveness variables

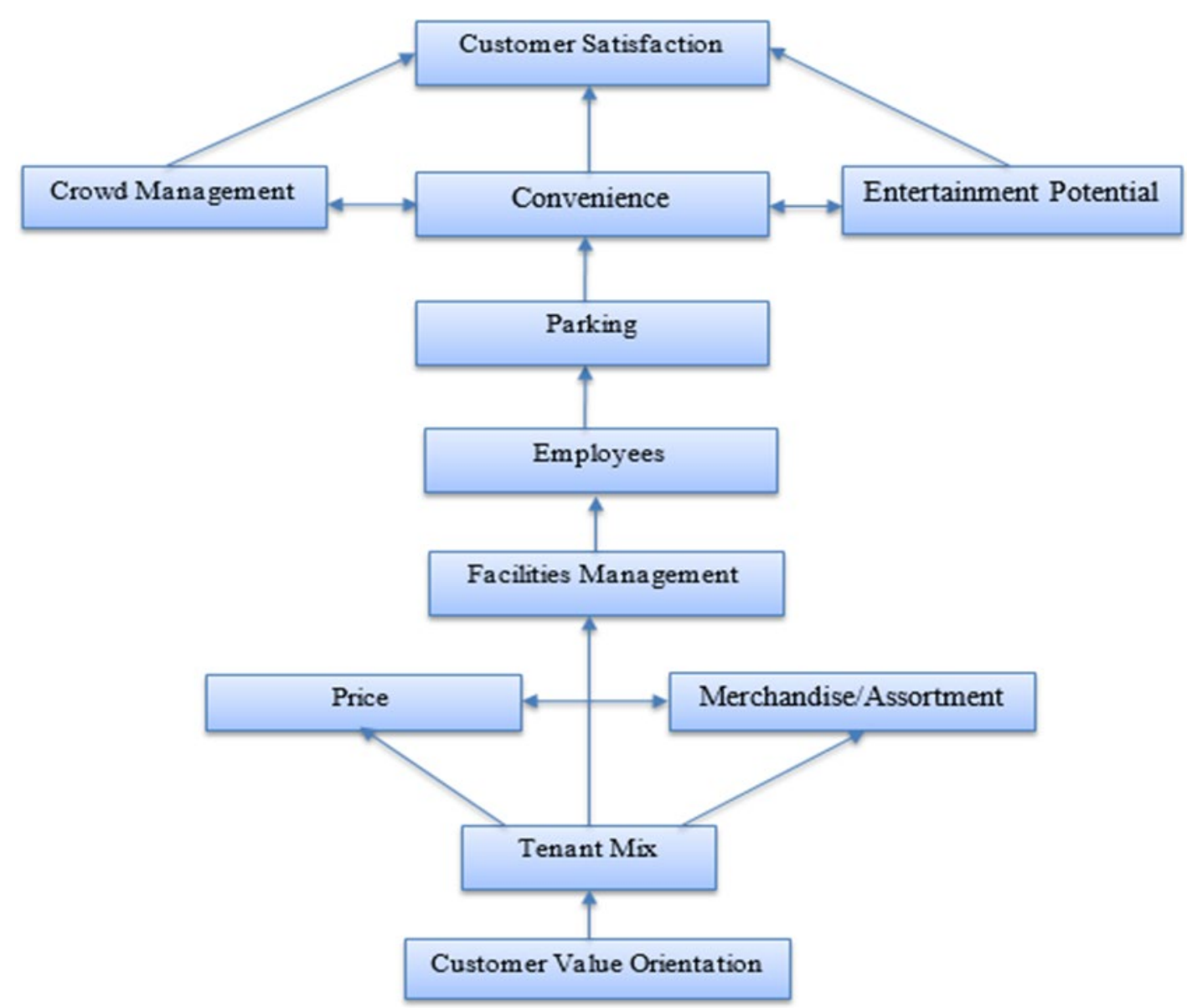

Figure 3: Final model depicting the relationship among the customer experience and mall attractiveness variables 


\section{MICMAC Analysis}

This technique was developed by J.C. Duperrin and M. Godet between 1972 and 1974. MICMAC Analysis stands for: "matrice d'impacts croises - multiplication applique' a un classement" (cross impact matrix-multiplication applied to classification). MICMAC determines the dependence power and driving power of enablers and categories them into four heads- dominant, relay, dominated and autonomous (Godet et al., 2003). Mandal and Deshmukh (1994) and Thakkar et al., (2008) tried to identify the driving power and dependence power of knowledge management variables and ITenablers for Indian manufacturing SMEs respectively using MICMAC analysis. In MICMAC analysis, all the factors are categorized into four clusters. Cluster I indicate 'autonomous variables' which has a weak dependence and weak driving power. It possesses weak links with other variables and hence, stay disconnected from the system. Cluster II indicates 'dependent variables' which has a strong dependence but weak driving power. Cluster III indicates s 'linkage variables' which has a strong driving power and strong dependence.

Any change in these variables affects other variables. These variables also get affected by feedback. Hence, they are considered unstable. Cluster IV indicates 'independent variables' which has weak dependence but strong driving power.

\begin{tabular}{|l|l|l|l|l|l|l|l|l|l|l|l|}
\hline 11 & & & & & IV & & & & & & III \\
\hline 10 & & & & & & & & & & & \\
\hline 9 & & & & & & & & & & & \\
\hline 8 & & & & & & & & & & & \\
\hline 7 & & & 5 & & & & & & & & \\
\hline 6 & & 2,9 & & & & & & & & & \\
\hline 5 & & & & 1 & $I$ & & & & & & II \\
\hline 4 & & & & & 3,7 & & & 6 & & & \\
\hline 3 & & & & & & & & & & & \\
\hline 2 & & & & & & & & & & & \\
\hline 1 & & & 4,8 & & & & & & & & 11 \\
\hline & 1 & 2 & 3 & 4 & 5 & 6 & 7 & 8 & 9 & 10 & 11 \\
\hline
\end{tabular}

Figure 4: Cluster of retail and mall experience variables

\section{DISCUSSION}

The present study attempts to identify the variables associated with retail experiences that may attract customers in Tier III cities towards the malls. This study found that customers' value orientation has a major influence on their experience of a mall. Customers' proclivity towards derivation of emotional, utilitarian, economic, social or economic value, differentially affects their evaluation of various mall attractiveness dimensions. The results of current study were congruent with Aliaghaa et al., (2015), as they found attractiveness, locality of mall's customer, price, facilities and parking as the most important point to attract customer. Understanding customers' value orientation offers retailers a key insight into understanding their expressed, as well as latent needs, and to strategize the right retail mix and positively amplify their experiences to inculcate customer satisfaction. This indicates that the first benchmark for creating appealing mall experiences would be to align malls along with particular consumer value orientation. 
The second level identified by the analysis is Tenant Management, which holds the potential for becoming a strong driving factor for mall experiences. Retailers should carefully tailor an optimal tenant mix to include retail formats with a blend of play zones, multiplexes, restaurants etc. according to mall size, and targeted consumers within its trade areas. A well - planned tenant mix has the capability to create a synergizing theme for the mall that cohesively connects the various tenants present in the mall. To strategize an optimal tenant mix, mall managers can identify the most well performing malls in their cities for benchmarking best retail practices, these benchmarks can be used for identifying a suitable positioning platform and competitive tenant mixes for individual malls. An optimal tenant mix also ensures availability of merchandise assortment which carries significant connotations for utility-oriented customers going to malls for shopping and purchase oriented activities. For such customers, availability of a variety of stores and merchandise assortment grants the mall a competitive edge by delivering value to customers and influencing they're revisit intentions.

Additionally, for utility-oriented customers competitive pricing strategies and availability of stores with differentially priced merchandise acts as a value driver. Pricing thus emerges as a mall attractiveness dimension, equivalently important as merchandise, for Tier III customers. Facilities Management emerges as the next significant variable affecting customer satisfaction and experience in Tier III cities. Mall facilities include flooring, seating arrangement, washrooms, ATM, elevators and parking which leads to an enjoyable shopping experience. These elements also assist customers' access to and movement within the mall, while fulfill their needs of a convenient and facilitative shopping environment. By understanding and providing attractive facility elements, the management or a mall owner can develop a differentiating benchmark and competitive advantage in the competitive retail industry. Employees are placed at the $\mathrm{V}$ level as an Attractiveness dimension for Tier III city Indian customers. As retail is a service-oriented business, employee behavior may significantly contribute to transmuting the actual experience to consumers. The mall managers should ensure that employees are well trained to address customers' need for social interaction in the retail environment while fulfilling their utilitarian expectations such as knowledge of store offers, merchandise availability, product knowledge etc. such relationship with customer entice them to re-visit store.

Surprisingly, parking emerges as a significant predictor of mall experiences for Tier III consumers. This suggests that adequate availability of parking space may influence customers' visit intentions by reducing their psychic shopping costs, such as time, travel and safety associated with visiting a mall. Furthermore, customer satisfaction and experience in small-town malls are affected by three other dimensions - convenience, crowd management and entertainment potential. Similar results were found in the study of Ahmad (2012) which found convenience, accessibility, and entertainment as very important in mall shoppers' satisfaction based in Saudi Arabia. Crowds may positively or negatively influence customers depending upon their value orientation. Where a utilitarian customer with expectations of a convenient shopping destination would find crowds a deterrent and may negatively influence his/her satisfaction; a hedonically-oriented customer would enjoy the socialization and entertainment potential of a well-managed crowd. Convenience and entertainment potential of a mall reflect customers' utilitarian and hedonic orientations and directly influence customer satisfaction. On the other hand, convenience and accessibility to a mall would be more influenced by the dimensions of facilities and would attract utility-oriented shoppers. A mall's orientation towards entertainment could thus become its differentiating strength by creating a synergetic relationship between retailing and recreation.

\section{CONCLUSION}

The identification of mall attractiveness dimensions for small towns and cities along with consideration 
of metropolitan cities may help retailers in developing a standardized Mall Attractiveness Index. Such a tool can lend retailers' a hand in developing a benchmark for mall managers to recognize individual dimensions that can help them in creating a unique brand proposition for malls. This study suggests that foreknowledge of target populations' shopping orientations should be obtained through a thorough catchment area analysis prior to building a mall's business model. This would help understand customers' demographic profiles, spending power, per capita income and shopping aspirations; giving retailers a chance to develop malls as individual brands. Consideration of customer preferences in this process can pave the way to induce brand love for a mall amongst the intended target markets.

\section{LIMITATIONS AND FUTURE SCOPE}

The present paper aims at understanding variables affecting customer experience in Tier III cities. However, the limitations of this study opens up opportunities for further research. There is a significant scope to expand this study's premise to other small-town locations to gain insight to mall experiences. Furthermore, the Indian retail market is in relatively in different stages of development and evolution due to a noteworthy rural - urban divide. An inclusive study covering significant metropolitan and small-town locations can help in developing a holistic view of the concept of mall experiences for Indian consumers. Such insights would be invaluable for retailers hoping to maintain their positions in the relatively saturated metropolitan cities while attempting to create their own niches among the masses of small towns that comprise India's extensive retail market. There is also scope to translate the results of this qualitative study into a quantitative research to gather intelligible and actionable data. As industries, especially retail, moves towards adoption of data - driven insights for executing marketing strategies, such a study could potentially hold immense significance for retailers. 


\section{REFERENCES}

Abghari, M., \& Hanzaee, K. H. (2011). Investigation of the effects of stores' tenant mix and internal and external environmental conditions on customer satisfaction from shopping centers in Iran. International Journal of Marketing Studies, 3(4), 158-164.

Adufutse, W. Y. (2010). Customer service experience: A quantitative analysis of frontline employees' and customers' perceptions in the fast food industry. Walden University.

Ahmad, A. M. K. (2012). Attractiveness Factors Influencing Shoppers' Satisfaction, Loyalty, and Word of Mouth: An Empirical Investigation of Saudi Arabia Shopping Malls. International Journal of Business Administration, 3(6), 101-112.

Ajmera, P., \& Jain, V. (2019). Modeling the factors affecting the quality of life in diabetic patients in India using total interpretive structural modeling. Benchmarking: An International Journal, 26(3).

Aliagha, G. U., Qin, Y. G., Ali, K. N., \& Abdullah, M. N. (2015). Analysis of Shopping Mall Attractiveness and Customer Loyalty. Jurnal Teknologi, 74(2), 15-21.

Allen, S. (2009). An empirical study of the components of value co-creation (PhD). Carleton University.

Angelis, J., de Lima, E. P., \& Širaliova, J. (2010). Servitised Experiences: Business and Management Implications. Current Issues of Business and Law, 5, 1-11.

Arnold, M. J., \& Reynolds, K. E. (2003). Hedonic shopping motivations. Journal of Retailing, Vol. 79(2), 77-95.

Arnould, E.J., Price, L.L. and Zinkhan, G. (2002). Consumers, 1st edition, New York: McGraw-Hill.

Attri, R., Singh, B. and Mehra, S. (2017). Analysis of interaction among the barriers to 5 S implementation using interpretive structural modelling approach. Benchmarking: An International Journal, 24(7), 1834-1853.

Babar, K., \& Khan, S. (2019). "India to get over 65 million sq ft new mall space by 2022-end”, available at: https://economictimes.indiatimes.com/industry/services/property-/-cstruction/india-to-getover-65-million-sq-ft-new-mall-space-by-2022-endreport/articleshow/69989406.cms?from=mdr (accessed 01 October 2019).

Babin, B. J., Darden, W. R., \& Griffin, M. (1994). Work and/or fun: measuring hedonic and utilitarian shopping value. Journal of consumer research, 20(4), 644-656.

Bäckström, K. (2006). Understanding recreational shopping: A new approach. International Review of Retail, Distribution and Consumer Research, 16(02), 143-158.

Baker, J., \& Wakefield, K. L. (2012). How consumer shopping orientation influences perceived crowding, excitement, and stress at the mall. Journal of the Academy of Marketing Science, 40(6), 791-806.

Baltas, G., \& Papastathopoulou, P. (2003). Shopper characteristics, product and store choice criteria: a survey in the Greek grocery sector. International Journal of Retail \& Distribution Management, 31(10), 498-507.

Banerjee, N. (2012). A Study on The Attractiveness Dimensions of Shopping Malls-An Indian Perspective. International Journal of Business and Social Science, 3(2), 102-112.

Batra, R., \& Ahtola, O. T. (1991). Measuring the hedonic and utilitarian sources of consumer attitudes. Marketing letters, 2(2), 159-170.

Biswas, D., Grewal, D., \& Roggeveen, A. (2010). How the order of sampled experiential products affects choice. Journal of Marketing Research, 47(3), 508-519.

Blocker, C. P., Flint, D. J., Myers, M. B., \& Slater, S. F. (2011). Proactive customer orientation and its role for creating customer value in global markets. Journal of the Academy of Marketing Science, 39(2), 216-233. 
Bonnin, G., \& Goudey, A. (2012). The kinetic quality of store design: an exploration of its influence on shopping experience. Journal of Retailing and Consumer Services, 19(6), 637-643.

Borges, A., Chebat, J. C., \& Babin, B. J. (2010). Does a companion always enhance the shopping experience?. Journal of Retailing and Consumer Services, 17(4), 294-299.

Business Monitor International. (2012). India Retail Report Q1 2013. London: Business Monitor International Ltd.

Carbone, L. and Haeckel, S. (2005). Engineering Customer Experiences. Senseandrespond.com, available at: http://senseandrespond.com/downloads/Original_EE_Article_MM_1994.pdf (accessed 29 June 2019).

Care Ratings. (2019). Retail Industry Update: Outlook 2020. Available at: http://www.careratings.com/upload/NewsFiles/SplAnalysis/Retail\%20Industry\%20Update\%20a ug\%202019.pdf

Chaple, A. P., Narkhede, B. E., Akarte, M. M., \& Raut, R. (2018). Interpretive framework for analyzing lean implementation using ISM and IRP modeling. Benchmarking: An International Journal, 25(9), 3406-3442.

Cinjarevic, M., Tatic, K., \& Petric, S. (2011). See it, like it, buy it! Hedonic shopping motivations and impulse buying. Economic Review: Journal of Economics and Business, 9(1), 3-15.

Dalmoro, M., Isabella, G., de Almeida, S. O., \& dos Santos Fleck, J. P. (2019). Developing a holistic understanding of consumers' experiences. European Journal of Marketing, 53(10), 2054-2079

Davis, L., \& Hodges, N. (2012). Consumer shopping value: An investigation of shopping trip value, instore shopping value and retail format. Journal of retailing and consumer services, 19(2), 229239.

Donnelly, M. (2009). Building customer loyalty: a customer experience based approach in a tourism context (Doctoral dissertation, Waterford Institute of Technology).

Dungarwal, S. (2016). The Big Malls in small cities - Re-Tales by Susil S Dungarwal | ET Retail. available at: $\quad$ https://retail.economictimes.indiatimes.com/re-tales/the-big-malls-in-small-cities/1374 (accessed 28 April 2019).

Eroglu, S. A., \& Machleit, K. A. (1990). An empirical study of retail crowding: antecedents and consequences. Journal of retailing, 66(2), 201.

Eroglu, S. A., Machleit, K., \& Barr, T. F. (2005). Perceived retail crowding and shopping satisfaction: the role of shopping values. Journal of business research, 58(8), 1146-1153.

Faisal, M. N., Banwet, D. K., \& Shankar, R. (2006). Supply chain risk mitigation: modeling the enablers. Business Process Management Journal, 12(4), 535-52.

Ferguson, R. J., Paulin, M., \& Bergeron, J. (2010). Customer sociability and the total service experience. Journal of service management, 21(1), 25-44.

Fornell, C., Robinson, W. T., \& Wernerfelt, B. (1985). Consumption experience and sales promotion expenditure. Management Science, 31(9), 1084-1105.

Garg, R., Rahman, Z., \& Kumar, I. (2010). Evaluating a model for analyzing methods used for measuring customer experience. Journal of Database Marketing \& Customer Strategy Management, 17(2), 78-90.

Georgakopoulos, A. (2009). Teacher Effectiveness Examined as a System: Interpretive Structural Modeling and Facilitation Sessions with US and Japanese Students. International Education Studies, 2(3), 60-76.

Ghosh, P., Tripathi, V., \& Kumar, A. (2010). Customer expectations of store attributes: A study of organized retail outlets in India. Journal of Retail \& Leisure Property, 9(1), 75-87.

Godet, A. J., Meunier, M. F., \& Roubelat, F. (2003). Structural analysis with the MICMAC method \& actors' strategy with MACTOR method. Futures research methodology, 7-10. 
Grewal, D., Baker, J., Levy, M., \& Voss, G. B. (2003). The effects of wait expectations and store atmosphere evaluations on patronage intentions in service-intensive retail stores. Journal of retailing, 79(4), 259-268.

Grewal, D., Levy, M., \& Kumar, V. (2009). Customer experience management in retailing: An organizing framework. Journal of retailing, 85(1), 1-14.

Gunter, H. (2007). Remodelling the school workforce in England: a study in tyranny. Journal for Critical Education Policy Studies, 5(1), 1-11.

Han, H., Back, K. J., \& Barrett, B. (2010). A consumption emotion measurement development: a fullservice restaurant setting. The Service Industries Journal, 30(2), 299-320.

Hean, L. L., \& Tin, L. G. (2004). Relevance and Significance of Relationships: The Singapore Experience in Mentoring. International Studies in Educational Administration, 32(3).

Hui, E. C. M., Lau, H. T., \& Khan, T. H. (2011). Effect of property management on property price: a case study in HK.Facilities, 29(11), 459-471.

Hui, E., Zhang, P. H., \& Zheng, X. (2013). Facilities management service and customer satisfaction in shopping mall sector. Facilities, 31(5-6), 194-207.

Institute of Real Estate Management (1990). Leasing Retail Space. The Institute of Real Estate Management, Chicago, IL.

Jain, V., \& Ajmera, P. (2018). Modelling the factors affecting Indian medical tourism sector using interpretive structural modeling. Benchmarking: An International Journal, 25(5), 1461-1479.

JLL - CII (2017). Indian Retail - Change is the New Constant. [online] Chandigarh: Cll. Available at: http://www.asiapacific.joneslanglasalle.com/India/Mailers/tags_final_online.pdf (Accessed 16 Mar. 2018).

Joseph-Mathews, S., Bonn, M. A., \& Snepenger, D. (2009). Atmospherics and consumers' symbolic interpretations of hedonic services. International Journal of Culture, Tourism and Hospitality Research, 3(3), 193-210.

Kang, J., \& Hyun, S. S. (2012). Effective communication styles for the customer-oriented service employee: Inducing dedicational behaviors in luxury restaurant patrons. International Journal of Hospitality Management, 31(3), 772-785.

Kearney, A.T. (2012). Consumer Wealth and Spending: The $\$ 12$ Trillion Opportunity. Korea.

Kesari, B., \& Atulkar, S. (2016). Satisfaction of mall shoppers: A study on perceived utilitarian and hedonic shopping values. Journal of Retailing and Consumer services, 31, 22-31.

Khaba, S., \& Bhar, C. (2018). Analysing the barriers of lean in Indian coal mining industry using integrated ISM-MICMAC and SEM. Benchmarking: An International Journal, 25(7), 2145-2168.

Khan, I., \& Rahman, Z. (2015). Brand experience anatomy in retailing: An interpretive structural modeling approach. Journal of Retailing and Consumer Services, 24, 60-69.

Khan, I., \& Rahman, Z. (2017). Brand experience anatomy in hotels: an interpretive structural modeling approach. Cornell Hospitality Quarterly, 58(2), 165-178.

Khare, A., \& Rakesh, S. (2010). Retailers in malls: Retailers' preferences for store space in Indian malls. Journal of Retail \& Leisure Property, 9(2), 125-135.

Khare, A., Sarkar, S., \& Patel, S. S. (2019). Influence of culture, price perception and mall promotions on Indian consumers' commitment towards malls. International Journal of Retail \& Distribution Management, 47(10), 1093-1124.

Kim, H. Y. (2007). Toward customer love: investigating the antecedents and outcomes of satisfied customers' emotional attachments to retailers.

KPMG (2014). Indian Retail: The Next Growth Story. New Delhi: KPMG. pp. 1-13.

Kumar, S., \& Purbey, S. (2018). Benchmarking model for factors influencing creation of negative electronic word of mouth. Benchmarking: An International Journal, 25(9), 3592-3606. 
Kuruvilla, S. J., \& Joshi, N. (2010). Influence of demographics, psychographics, shopping orientation, mall shopping attitude and purchase patterns on mall patronage in India. Journal of Retailing and Consumer Services, 17(4), 259-269

Machleit, K. A., Kellaris, J. J., \& Eroglu, S. A. (1994). Human versus spatial dimensions of crowding perceptions in retail environments: A note on their measurement and effect on shopper satisfaction. Marketing Letters, 5(2), 183-194.

Majumdar, A. (2005). A model for customer loyalty for retail stores inside shopping malls-an Indian perspective. Journal of Services Research, 27(1), 5-21.

Mandal, A., \& Deshmukh, S. G. (1994). Vendor selection using interpretive structural modelling (ISM). International journal of operations \& production management, 14(6), 52-59.

Mascarenhas, O. A., Kesavan, R., \& Bernacchi, M. (2006). Lasting customer loyalty: a total customer experience approach. Journal of consumer marketing, 23(7), 397-405.

Mazursky, D., \& Jacoby, J. (1986). Exploring the development of store images. Journal of retailing, 62(2), 145-165.

Michon, R., Yu, H., Smith, D., \& Chebat, J. C. (2008). The influence of mall environment on female fashion shoppers' value and behaviour. Journal of Fashion Marketing and Management: An International Journal, 12(4), 456-468.

Musa, Z. N., \& Pitt, M. (2009). Defining facilities management service delivery in UK shopping centres. Journal of Retail \& Leisure Property, 8(3), 193-205.

Oliver, R. L. (1994). Conceptual issues in the structural analysis of consumption emotion, satisfaction, and quality: Evidence in a service setting. ACR North American Advances, 16-22.

Ooi, J., Ibrahim, M. F., Ooi, J. T., \& Sim, L. L. (2007). The magnetism of suburban shopping centers: do size and Cineplex matter?. Journal of Property Investment \& Finance, 25(2), 111-135.

Pan, X., \& Shankar, V. (2008). Meta Analysis of Regular Price, Deal, Promotional Price Elasticities. Working Paper, University of California, Riverside, CA.

Parekh, V., Manjrekar, P., \& Subramanian, N. V. (2011). Modern Retail Locations: Blessing or Disguise. SIES Journal of Management, $7(2)$.

Pine, B. J., \& Gilmore, J. (1999). The experience economy: work is theatre and every business a stage, Harvard.

Pons, F., Laroche, M., \& Mourali, M. (2006). Consumer reactions to crowded retail settings: Crosscultural differences between North America and the Middle East. Psychology \& Marketing, 23(7), 555-572.

Poulsson, S. H., \& Kale, S. H. (2004). The experience economy and commercial experiences. The Marketing Review, 4(3), 267-277.

Puccinelli, N. M., Goodstein, R. C., Grewal, D., Price, R., Raghubir, P., \& Stewart, D. (2009). Customer experience management in retailing: understanding the buying process. Journal of retailing, 85(1), 15-30.

PWC and FICCI. (2012). The Indian Kaleidoscope: Emerging trends in Retail. India: PricewaterhouseCoopers (PwC).

PwC. (2011). Winning in India's Retail Sector: Factors for Success. India: PricewaterhouseCoopers (PwC).

Rahman, M., Rashid M.C,. Kumar, J., \& Gupta, A. (2020, in press). Does consumer demographics effects store loyalty in departmental stores? Academy of Marketing Studies Journal, 24(4).

Rajagopal. (2011). Determinants of shopping behavior of urban consumers. Journal of International Consumer Marketing, 23(2), 83-104.

Rajaguru, R., \& Matanda, M. J. (2011). Functional Attributes and Shopping Value: Supermarket Vs Local Market. International Journal of Global Business, 4(2). 
Rajesh, R. (2017). Technological capabilities and supply chain resilience of firms: A relational analysis using Total Interpretive Structural Modeling (TISM). Technological Forecasting and Social Change, 118, 161-169.

Ramaswamy, V. (2009). Leading the transformation to co-creation of value. Strategy \& Leadership, $37(2), 32-37$.

Raut, R., Priyadarshinee, P., Jha, M., Gardas, B., \& Kamble, S. (2018). Modeling the implementation barriers of cloud computing adoption. Benchmarking: An International Journal, 25(8), 27602782.

Rondeau, K. V., \& Wagar, T. H. (2006). Nurse and resident satisfaction in magnet long-term care organizations: do high involvement approaches matter?. Journal of Nursing Management, 14(3), 244-250.

Ryu, K., \& Han, H. (2011). New or repeat customers: How does physical environment influence their restaurant experience?. International Journal of Hospitality Management, 30(3), 599-611.

Sadachar, A., \& Fiore, A. (2018). The path to mall patronage intentions is paved with 4E-based experiential value for Indian consumers. International Journal of Retail \& Distribution Management, 46(5), 442-465.

Sage, A.P. (1977) Interpretive Structural Modeling: Methodology for Large-scale Systems, pp.91-164, McGraw-Hill, New York, NY.

Sahney, S., Banwet, D., \& Karunes, S. (2010). Quality framework in education through application of interpretive structural modeling. The TQM Journal, 22(1), 56-71.

Sanguanpiyapan, T., \& Jasper, C. (2010). Consumer insights into luxury goods: Why they shop where they do in a jewellery shopping setting. Journal of Retailing and Consumer Services, 17(2), 152160.

Sarmah, B., \& Rahman, Z. (2018). Customer co-creation in hotel service innovation: An interpretive structural modeling and MICMAC analysis approach. Benchmarking: An International Journal, 25(1), 297-318.

Shaw, D., \& Haynes, B. (2004). An evaluation of customer perception of FM service delivery. Facilities, 22(7/8), 170-177.

Singh, A., \& Samuel, C. (2018). Modelling the strengthening factors for competitive position of apparel retailing in India. Journal of Modelling in Management, 13(4), 884-907.

Singh, H. and Srinivasan, S. R. (2012). Mall Management: Operating in Indian Retail Space. New Delhi: Tata McGraw Hill.

Singh, H., \& Prashar, S. (2014). Anatomy of shopping experience for malls in Mumbai: A confirmatory factor analysis approach. Journal of Retailing and Consumer Services, 21(2), 220-228.

Singh, H., \& Sahay, V. (2012). Determinants of shopping experience: Exploring the mall shoppers of national capital region (NCR) of India. International Journal of Retail \& Distribution Management, 40(3), 235-248.

Singh, M., Kant, S., \& Jawalkar, C. S. (2017). Development of Interpretive Structural Modeling: An Approach for Fertilizer Industries. I-Manager'S Journal On Mechanical Engineering, 7(2), 35-43.

Singh, R., and Cradit J. D. (2006). An empirical investigation into the effects of Shopping Motivation on Store environment-value relationship. available at:

http://etd.lib.fsu.edu/theses/available/etd-04182006-213703. (accessed 15 January 2020).

Sorescu, A., Frambach, R., Singh, J., Rangaswamy, A., \& Bridges, C. (2011). Innovations in Retail Business Models. Journal of Retailing, 87, S3-S16.

Srinivasan, S., \& Srivastava, R. (2010). Creating the futuristic retail experience through experiential marketing: Is it possible? An exploratory study. Journal of Retail \& Leisure Property, 9(3), 193199. 
Srivastava, M., \& Kaul, D. (2014). Social interaction, convenience and customer satisfaction: The mediating effect of customer experience. Journal of Retailing And Consumer Services, 21(6), 1028-1037.

Srivastava, S., Palande, P. and Hussain, S. (2015), "Behind the big fat Indian mall", available at: www.forbesindia.com/article/real-issue/behind-the-big-fat-indian-mall/39895/1 (accessed 01 October 2019).

Sushil, S. (2018), Interpretive multi-criteria valuation of flexibility initiatives on direct value chain. Benchmarking: An International Journal, 25(9), 3720-3742. doi: 10.1108/bij-03-2018-0057

Swaminathan, F.J. and Vani, V. (2008), "Consumer attitude colour growth of malls: Delhi NCR", Abhigyan, 26 (2), 44-51.

Tandon, A., Tripathi, V., \& Gupta, A. (2014). The transformation of value and evolution of customer experience: an exploration of the typologies, facets and significance. International Journal of Indian Culture And Business Management, 8(4), 425.

Tauber, E. (1972). Marketing notes and communications: Why do people shop?.Journal of Marketing, 36(4), 46-49.

Teller, C., \& Reutterer, T. (2008). The evolving concept of retail attractiveness: What makes retail agglomerations attractive when customers shop at them?. Journal of Retailing and Consumer Services, 15(3), 127-143.

Terblanche, N., \& Boshoff, C. (2004). The in-store shopping experience: A comparative study of supermarket and clothing store customers. South African Journal of Business Management, 35(4), 1-10.

Thakkar, J., Kanda, A., \& Deshmukh, S. G. (2008). Interpretive structural modeling (ISM) of IT-enablers for Indian manufacturing SMEs. Information Management \& Computer Security, 16(2), 113-136.

Torres, I., Summers, T., \& Belleau, B. (2001). Men's shopping satisfaction and store preferences. Journal of Retailing and Consumer Services, 8(4), 205-212.

Tsai, S. (2010). Shopping mall management and entertainment experience: a cross-regional investigation. The Service Industries Journal, 30(3), 321-337.

Velázquez, B. M., Blasco, M. F., Saura, I. G., \& Contrí, G. B. (2010). Causes for complaining behaviour intentions: the moderator effect of previous customer experience of the restaurant. Journal of Services Marketing, 24(7), 532-545.

Venkatesh, V. G., Rathi, S., \& Patwa, S. (2015). Analysis on supply chain risks in Indian apparel retail chains and proposal of risk prioritization model using Interpretive structural modeling. Journal of Retailing and Consumer Services, 26, 153-167.

Verma, H., \& Singh, S. (2018). Interpretive structural modelling for e-impulse buying: an Indian study. International Journal of Electronic Marketing and Retailing, 9(3), 288-306.

Voss, K., Spangenberg, E., \& Grohmann, B. (2003). Measuring the Hedonic and Utilitarian Dimensions of Consumer Attitude. Journal of Marketing Research, 40(3), 310-320.

Wakefield, K., \& Baker, J. (1998). Excitement at the mall: Determinants and effects on shopping response. Journal of Retailing, 74(4), 515-539.

Warfield, J. (1976) Societal Systems: Planning, Policy and Complexity, John Wiley \& Sons, Inc., New York, NY.

Webster, C., \& Sundaram, D. (2009). Effect of service provider's communication style on customer satisfaction in professional services setting: the moderating role of criticality and service nature. Journal of Services Marketing, 23(2), 103-113.

Willems, K., Janssens, W., Swinnen, G., Brengman, M., Streukens, S., \& Vancauteren, M. (2012). From Armani to Zara: Impression formation based on fashion store patronage. Journal of Business Research, 65(10), 1487-1494. 
Yu, C., \& Bastin, M. (2010). Hedonic shopping value and impulse buying behavior in transitional economies: A symbiosis in the Mainland China marketplace. Journal of Brand Management, 18(2), 105-114.

Yuan, Y., \& Wu, C. (2008). Relationships Among Experiential Marketing, Experiential Value, and Customer Satisfaction. Journal of Hospitality \& Tourism Research, 32(3), 387-410. 